\title{
Involvement of Glutathione, Sulfhydryl Compounds, Nitric Oxide, Vasoactive Intestinal Peptide, and Heat-Shock Protein-70 in the Gastroprotective Mechanism of Croton cajucara Benth. (Euphorbiaceae) Essential Oil
}

\author{
Ariane Leite Rozza, Thiago de Mello Moraes, ${ }^{2}$ Hélio Kushima, ${ }^{2}$ Domingos Sávio Nunes, ${ }^{3}$ \\ Clélia Akiko Hiruma-Lima, ${ }^{2}$ and Cláudia Helena Pellizzon ${ }^{1}$
} Departments of ${ }^{1}$ Morphology and ${ }^{2}$ Physiology, Biosciences Institute, Universidade Estadual Paulista, Botucatu, São Paulo, Brazil.
${ }^{3}$ Department of Chemistry, Universidade Estadual de Ponta Grossa, Ponta Grossa, Paraná, Brazil.

\begin{abstract}
This study aimed to evaluate the gastroprotective mechanism of action of the essential oil of Croton cajucara Benth. (Euphorbiaceae) stem bark in ethanol-induced gastric ulcers and its in vitro anti-Helicobacter pylori activity. The involvement of heat-shock protein-70, vasoactive intestinal peptide, glutathione, nitric oxide, and nonprotein sulfhydryl compounds in the gastroprotective effect was determined in male Wistar rats. The minimum inhibitory concentration against H. pylori was determined in vitro. The results were analyzed by analysis of variance followed by the Dunnett test, and a $P$ value less than 0.05 was considered to represent a statistically significant difference. C. cajucara decreased ethanol-induced ulcer area in $100 \%$ of ulcers and decreased the histologic lesions. In the C. cajucara group, the area marked by heat-shock protein-70 was significantly higher than the area in the control group; this finding was not seen for vasoactive intestinal peptide. C. cajucara could not maintain glutathione levels close to those in the sham group. The gastric ulcer area of rats treated with the sulfhydryl compound blocker was decreased, but the ulcer area of rats treated with nitric oxide synthase inhibitor showed no alteration. The minimum inhibitory concentration obtained for C. cajucara was $125 \mu \mathrm{g} / \mathrm{mL}$. These findings suggest that sulfhydryl compounds and heat-shock protein-70, but not nitric oxide, glutathione, or vasoactive intestinal peptide, are involved in the $C$. cajucara gastroprotective effect against ethanol-induced gastric ulcers.
\end{abstract}

KEY WORDS: $\bullet$ Croton cajucara $\bullet$ essential oil $\bullet$ gastroprotection $\bullet$ glutathione $\bullet$ heat-shock protein-70 $\bullet$ medicinal plants • nitric oxide • sulfhydryl compounds

\section{INTRODUCTION}

$\mathbf{F}$ OLK MEDICINE IS ESPECIALLY IMPORTANT in developing countries. In Brazil, information from ethnic groups on traditional medicine has played a vital role in the discovery of novel therapeutic agents from plants. ${ }^{1}$ An increasing number of studies have shown that several Brazilian plantderived essential oils exhibit a variety of biological properties, such as analgesic, ${ }^{2}$ anticonvulsant, ${ }^{3}$ and antiulcerogenic activities. ${ }^{4}$ Naturally sourced medicines have become increasingly popular among consumers searching for natural ways to maintain their health. ${ }^{5}$

Plant extracts have been used to treat gastric disorders for many centuries. Gastric and duodenal ulcers are illnesses that affect a large number of people worldwide. Stress, smoking, nutritional deficiencies, ingestion of nonsteroidal antiinflammatory drugs, presence of the bacteria Helicobacter pylori in the stomach, and ethanol ingestion increase the

Manuscript received 7 July 2010. Revision accepted 13 October 2010.

Address correspondence to: Profa. Dra. Cláudia Helena Pellizzon, Morphology Department, Institute of Biosciences, UNESP, P.O. Box 510, 18618-000, Botucatu/SP, Brazil, E-mail: claudia@ibb.unesp.br incidence of gastric ulcer lesions. ${ }^{6}$ Even normal acid secretion can cause ulceration if some gastroprotective factors are overwhelmed. $^{7}$ Although there are many products on the market for the treatment of gastric ulcers, including antacids, proton-pump inhibitors, anticholinergics, and histamine-2 antagonists, most of these drugs produce several adverse reactions, such as hypersensitivity, arrhythmia, impotence, gynecomastia, and hematopoietic changes. ${ }^{8}$ Thus, more effective and less toxic antiulcer agents are needed.

Croton cajucara Benth. (Euphorbiaceae), popularly known as sacaca ("sorcery" in the Tupi Indian language), is a native plant from the Amazon rainforest with a medicinal property important in Amazonian folk medicine. The tree is 6-10 meters in height. The leaves are glabrous in the ventral face and pubescent in the dorsal face. The inflorescences are racemes of 9-cm length, with 7 feminine flowers in the base and 12 masculine flowers in the terminal portion of the raceme. The fruits are globose capsule, tricoca, and dehiscent. ${ }^{9}$ It is a well-known medicinal plant used to treat several illnesses, such as diarrhea, diabetes, and liver inflammation, and to control cholesterol levels. ${ }^{10}$ In addition, this plant is used in the treatment of stomachache, fever, jaundice, hepatitis, and malaria. ${ }^{11}$ After infusion, the 
C. cajucara stem bark is consumed in cases of heartburn, gastritis, and peptic ulcer. ${ }^{12}$ It is one of the most important Brazilian medicinal plants. ${ }^{13}$

C. cajucara essential oil prevents acute gastric lesion formation and accelerates the healing of acetic acid-induced gastric ulcers. ${ }^{4}$ Its antiulcerogenic effect was attributed to the presence of $\mathrm{C}_{15} \mathrm{H}_{24}$ sesquiterpene-like cyperene (29.0\%) and $\alpha$-copaene (20.9\%), which were found to be the main components of the essential oil. ${ }^{14}$

Our study aimed to evaluate the gastroprotective effects of $C$. cajucara essential oil in ethanol-induced gastric ulcers. We sought to elucidate whether its mechanism of action is associated with nitric oxide, sulfhydryl compounds, and glutathione, and we focused on its histologic alterations. Furthermore, we also evaluated the in vitro activity of $C$. cajucara against $H$. pylori.

\section{MATERIAL AND METHODS}

\section{Animals}

Male Wistar rats (weighing 200-250 g) from the Central Animal House of Universidade Estadual Paulista (UNESP) were used. They were fed a certified Nuvilab (Nuvital) diet and had free access to tap water under standard conditions of lighting (12 hours dark/12 hours light), humidity (mean \pm standard deviation, $60 \% \pm 1 \%$ ), and temperature $\left(21 \pm 2^{\circ} \mathrm{C}\right)$. The rats were fasted before all assays because treatments were orally administered, and they were kept in cages with raised floors of wide mesh to prevent coprophagy. Seven rats were used for each group. The vehicle used was $8 \%$ polysorbate $80(10 \mathrm{~mL} / \mathrm{kg})$. All experiments followed the recommendations of the Canadian Council on Animal Care, and all protocols were approved by the UNESP Institutional Animal Care and Use Committee.

\section{Plant material and essential oil extraction and dose used}

C. cajucara was collected during the dry season in Santarém, Pará State, Brazil. A voucher specimen (number 247) has been identified by Nelson A. Rosa and deposited in the IAN Herbarium in Belém, Brazil. The presence of both the diterpene desidrocrotonin and the triterpene acetylaleuritolic acid in the chloroform extract of the bark was determined by thin-layer chromatography; this analysis was used to authenticate the plant material. ${ }^{15,16}$ The air-dried barks were milled and subjected to hydrodistillation for 5 hours, yielding $0.85 \%(\mathrm{w} / \mathrm{w})$ of the essential oil.

The dose of $100 \mathrm{mg} / \mathrm{kg}$ was chosen according to the literature. ${ }^{17}$

\section{Ethanol-induced gastric ulcers}

The experiment was performed as described by Morimoto et al. ${ }^{18}$ Male Wistar rats, having fasted for 24 hours, were distributed into 4 groups $(n=7)$. The animals orally received vehicle $(8 \%$ polysorbate $80,10 \mathrm{mg} / \mathrm{kg}$ ), carbenoxolone as the positive control $(100 \mathrm{mg} / \mathrm{kg})$, or C. cajucara $(100 \mathrm{mg} / \mathrm{kg})$. A sham group did not receive any drug or treatment. After 1 hour, the animals orally received $1 \mathrm{~mL}$ of absolute ethanol.
Animals were killed in the $\mathrm{CO}_{2}$ chamber after 1 additional hour, and the stomachs were removed, opened along the greater curvature, and scanned; the ulcer area $\left(\mathrm{mm}^{2}\right)$ was determined by AVSoft BioView software. A small fragment of each stomach was collected for measurement of glutathione levels. Stomach samples were used for histologic slides confection; they were stained with hematoxylin-eosin to analyze morphologic and histologic characteristics and with periodic acid-Schiff to demonstrate the mucus secretion. Samples were also submitted for immunocytochemistry analyses. A microscopic score ${ }^{19}$ was determined for epithelial desquamation, hemorrhage, glandular damage, and eosinophilic infiltration by using a scale ranging from 0 to 3 (0: none, 1: mild, 2: moderate, and 3: severe) for each criterion. The total score was 12 .

\section{Immunocytochemistry analyses}

Twenty-four slides were deparaffinized, rehydrated, and immunostained by the avidin-biotin complex method to detect heat-shock protein-70 (HSP-70) and vasoactive intestinal peptide (VIP). The antibodies were provided by Santa Cruz Biotechnology. Nonspecific reaction was blocked with $\mathrm{H}_{2} \mathrm{O}_{2}$ and goat serum before the incubation with the specific antiserum. After rinsing in phosphatasebuffered saline (PBS; $0.01 \mathrm{~mol} / \mathrm{L} ; \mathrm{pH}, 7.4)$, the sections were incubated in secondary antiserum (avidin-biotin complex kit). They were washed in PBS, the avidin-biotin complex was applied, and the reaction was finally carried out in a 3,3'-diaminobenzidine-tetrahydrochloride solution containing $0.01 \% \mathrm{H}_{2} \mathrm{O}_{2}$ in PBS. After immunostaining, the sections were lightly counterstained with hematoxylin and the immunoreactive cells were observed under a Leica microscope associated with Leica Qwin Software. For the control reaction, some slides were processed with omission of the primary antibody, and other slides omitted the primary and secondary antibodies. Twelve slides were used for each antibody, in which the marked area $\left(\mu \mathrm{m}^{2}\right)$ for both was measured with the aid of AVSoft BioView software.

\section{Determination of glutathione level}

Total glutathione content was quantified with the recycling assay. ${ }^{20}$ Samples of stomachs submitted to ethanolinduced gastric ulcer were thawed, minced, diluted 1:20 $(\mathrm{w} / \mathrm{v})$ in ice-cold 5\% (w/v) trichloroacetic acid, and homogenized. The homogenates were centrifuged at $7000 \mathrm{~g}$ for 15 minutes at $4^{\circ} \mathrm{C}$, and the supernatants were used to quantify glutathione content through reaction with 5,5'-ditiobis-2nitrobenzoic acid; the absorbance was read in a spectrophotometer $(412 \mathrm{~nm})$. The results were expressed as nmol glutathione/g tissue.

\section{Ethanol-induced gastric ulcers in NEM- or L-NAME-pretreated rats}

Having fasted for 24 hours, the male Wistar rats were distributed into 6 groups $(n=7)$. Two groups of rats were intraperitoneally treated with N-ethylmaleimide (NEM), 
$10 \mathrm{mg} / \mathrm{kg}$, a sulfhydryl compound-blocker; 2 groups were intraperitoneally treated with $\mathrm{N}$-nitro-L-arginine methyl ester (L-NAME), $70 \mathrm{mg} / \mathrm{kg}$, a nitric oxide synthase inhibitor; and 2 groups were treated with saline $(10 \mathrm{~mL} / \mathrm{kg}$, used as the vehicle for NEM and L-NAME). Thirty minutes later, $8 \%$ polysorbate $80(10 \mathrm{~mL} / \mathrm{kg})$ and C. cajucara $(100 \mathrm{mg} / \mathrm{kg})$ were orally administered to 3 groups each. After 60 minutes, all groups were orally treated with $1 \mathrm{~mL}$ of absolute ethanol for gastric ulcer induction. ${ }^{21}$ Animals were killed 1 hour after the ethanol administration and the stomachs were removed, opened along the greater curvature, and scanned. The ulcer area $\left(\mathrm{mm}^{2}\right)$ was determined by using AVSoft BioView software.

\section{In vitro anti-H. pylori activity}

Bacterial strains and culture conditions were as follows: culture of $\mathrm{H}$. pylori (ATCC 43504 ) was stored at $-80^{\circ} \mathrm{C}$ on Müller-Hinton broth containing 5\% bovine calf serum and $20 \%$ glycerol. Stocks were subcultured on Müller-Hinton agar, to which $10 \%$ sheep blood was added; the result was incubated at $37^{\circ} \mathrm{C}$ for 72 hours in a microaerobic atmosphere $\left(80 \% \mathrm{~N}_{2}, 15 \% \mathrm{CO}_{2}\right.$, and $\left.5 \% \mathrm{O}_{2}\right)$ with $98 \%$ humidity. The cells were suspended in sterile saline to obtain turbidity equivalent to a 2.0 McFarland standard (approximately 108 colony-forming units $/ \mathrm{mL})^{22}$

Broth microdilution procedure was used to evaluate the antibacterial activity. The minimum inhibitory concentration (MIC) was determined by using a dilution assay in a 96well microtiter plate. One hundred $\mu \mathrm{L}$ of Müller-Hinton broth containing $10 \%$ horse serum was added to all 96 wells of the microtiter plate (Corning). Each microplate was incubated with bacteria $(100 \mu \mathrm{L})$ at a final concentration of about 107 colony-forming units/mL plus $20 \mu \mathrm{L}$ of solution from each dilution of $C$. cajucara at concentrations between $1000 \mu \mathrm{L}$ and $6.25 \mu \mathrm{g} / \mathrm{mL}$ using 2 -fold serial dilutions. The plates were incubated for 3 days in a microaerobic atmosphere at $37^{\circ} \mathrm{C}$ and then examined visually and spectrophotometrically to determine the lowest concentration showing complete growth inhibition. This value was recorded as the MIC, in accordance with the Clinical and Laboratory Standards Institute. ${ }^{23}$

\section{Statistical analysis}

Parametric data were analyzed by using 1-way analysis of variance, followed by the Dunnett multiple comparison post hoc test. Results are presented as mean \pm standard error. Nonparametric data (histologic scoring) were analyzed by using the Kruskal-Wallis (nonparametric analysis of variance) test followed by the Dunn multiple comparison post hoc test. Results are presented as median (range). All analyses were performed by using GraphPad Instat software. A $P$ value less than .05 was considered to represent a statistically significant difference.

\section{RESULTS}

\section{Ethanol-induced gastric ulcers}

In the vehicle group, severe mucosal lesions were observed, consisting of elongated bands parallel to the long axis of the stomach. This group presented a mean ulcer area of $156.60 \pm 36.30 \mathrm{~mm}^{2}$. In contrast, C. cajucara completely prevented gastric ulcer formation. The ulcer area was $0.00 \pm 0.00 \mathrm{~mm}^{2}(P<.01)$, indicating that $C$. cajucara offered $100 \%$ gastroprotection. All 7 stomachs examined from the $C$. cajucara group were completely protected from any visible damage. The group receiving the positive

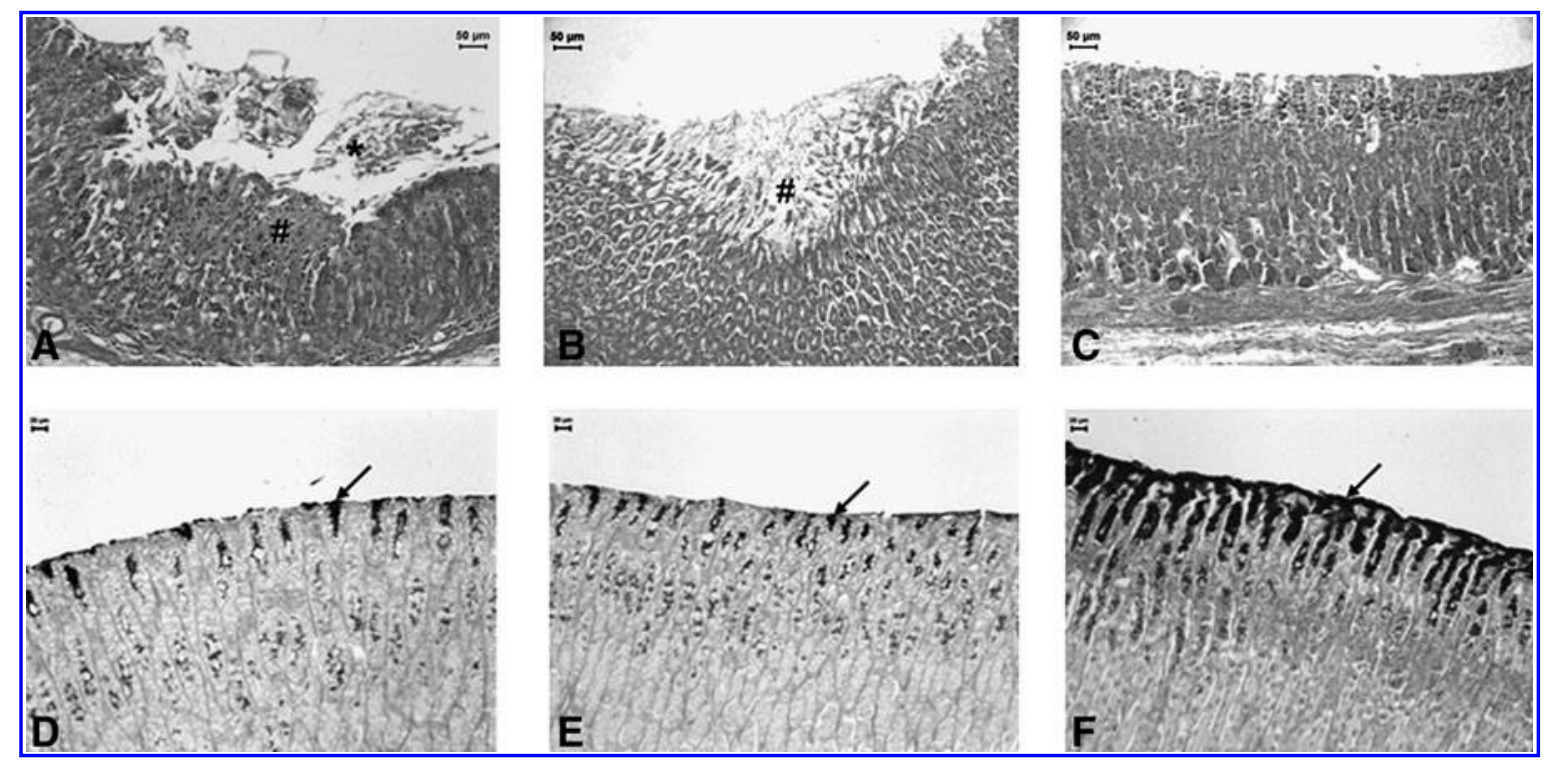

FIG 1. Photomicrographs of rats' stomach submitted to ethanol-induced gastric ulcer after treatment with vehicle (A, D), carbenoxolone $(100 \mathrm{mg} / \mathrm{kg})(\mathbf{B}, \mathbf{E})$, or C. cajucara $(100 \mathrm{mg} / \mathrm{kg})(\mathbf{C}, \mathbf{F})$. Hematoxylin-eosin staining (A-C) or periodic acid-Schiff staining (D-F); original magnification, $\times 320 . *$ indicates epithelial desquamation and \# indicates glandular damage. Arrows indicate mucous secretion. 
Table 1. Histologic Score and Immunoreactive Area for HSP-70 and VIP in Rats' Stomachs ( $N=7$ ) Submitted to Ethanol-Induced Gastric Ulcer After Treatment With Vehicle, Carbenoxolone (100 MG/Kg), or C. CaJuCara (100 MG/KG)

\begin{tabular}{lccc}
\hline Analysis & Vehicle & Carbenoxolone & C. cajucara \\
\hline Median score $(\text { range })^{\mathrm{a}}$ & $12(11-12)$ & $6(5-7)$ & $2(1-3)^{* * *}$ \\
HSP-70 $\left(\mu \mathrm{m}^{2}\right)^{\mathrm{b}}$ & $34.33 \pm 6.32$ & $168.88 \pm 19.40 * *$ & $105.13 \pm 9.47 * *$ \\
VIP $\left(\mu \mathrm{m}^{2}\right)^{\mathrm{b}}$ & $118.57 \pm 28.70$ & $114.88 \pm 24.52$ & $45.71 \pm 10.60$ \\
\hline
\end{tabular}

${ }^{\text {a }}$ Score was assessed by analysis of variance testing followed by the Dunn test; comparisons to vehicle, $* * * P<.001$.

${ }^{\mathrm{b}} \mathrm{HSP}-70$ and VIP values are expressed as mean \pm standard error. They were assessed by analysis of variance testing followed by the Dunnett test; comparison to vehicle, $* * P<.01$.

HSP-70, heat-shock protein-70; VIP, vasoactive intestinal peptide.

control carbenoxolone presented a mean ulcer area of $22.27 \pm 8.21 \mathrm{~mm}^{2}(P<.01)$; gastroprotection in this group was $85.8 \%$.

\section{Histologic analyses}

When compared with the control, the $C$. cajucara group presented a well-preserved gastric mucosa with no hemorrhage or eosinophilic infiltration and mild epithelial desquamation and glandular damage. The total score for the $C$. cajucara group was 2 (range, $1-3)(P<.001)$. The group treated with carbenoxolone obtained a total score of 6 (range, 5-7); epithelial preservation in this group was worse than that in the $C$. cajucara group, with moderate epithelial desquamation, hemorrhage, and glandular damage and mild eosinophilic infiltration. The score in the vehicle group was 12 (range, 11-12). Figure 1 (parts A-C) and Table 1 illustrate these results.

C. cajucara treatment led to the development of a substantial continuous periodic acid-Schiff-positive mucous gel layer that came to cover the surface of the gastric mucosa. A bright purple-stained area covering the mucosa and extending up to the gastric pits was noted, which indicates that $C$. cajucara treatment stimulated mucous production. This area is represented by the dark area in parts D-F of Figure 1.

\section{Immunohistochemical analyses}

The $C$. cajucara and carbenoxolone groups marked HSP70-positive cells, and the immunostained area was significantly larger $(P<.01)$ than in the vehicle group. This finding indicates that HSP-70 is part of the cytoprotective mechanism of action from C. cajucara (Table 1). Further, immunostaining remained concentrated in lesion areas, confirming that the treatment stimulated the adaptive cellular protection through HSP-70 activity (data not shown).

The immunostained area for VIP did not differ among the 3 groups (Table 1). There were a few VIP-positive cells in all groups (data not shown). C. cajucara did not increase VIP levels compared with the control groups.

\section{Determination of glutathione level}

In the $C$. cajucara group, glutathione was not maintained at levels close to those of the sham group (Fig. 2) after administration of the glutathione-depleting ethanol. This effect was also seen in the control groups, but the statistical difference between the positive and negative control groups and the sham group were higher $(P<.01)$ than the difference between the $C$. cajucara and sham groups $(P<.05)$. These observations indicate that the gastroprotective effect of $C$. cajucara does not act via this antioxidant pathway.

\section{Ethanol-induced gastric ulcers in NEM- or L-NAME-pretreated rats}

Pretreatment with NEM, a sulfhydryl-blocker, significantly increased the gastric ulcer area of animals treated with $C$. cajucara (Table 2) compared with saline-pretreated animals. This finding suggests that endogenous sulfhydryl is involved in the gastroprotective effect of $C$. cajucara.

Pretreatment with L-NAME, a nitric oxide-blocker, did not increase the gastric lesions of animals treated with $C$. cajucara (Table 2), indicating that nitric oxide is not involved in the gastroprotective effect of $C$. cajucara.

In vitro anti-H. pylori activity

The MIC obtained for CC was $125 \mu \mathrm{g} / \mathrm{mL}$.

\section{DISCUSSION}

Gastric ulcers induced by absolute ethanol are predominant in the glandular portion of the stomach. Ethanol administra-

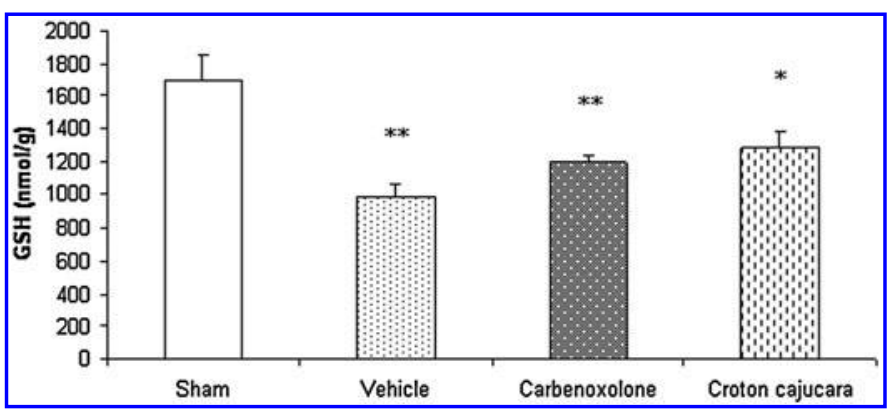

FIG 2. Glutathione levels in rats' stomachs $(n=7)$ submitted to ethanol-induced gastric ulcer after treatment with vehicle, carbenoxolone $(100 \mathrm{mg} / \mathrm{kg})$, or C. cajucara $(100 \mathrm{mg} / \mathrm{kg})$. Values are expressed as the mean \pm standard error. $* P<.05 ; * * P<.01$. Levels were as follows: sham group, $1704.30 \pm 149.03 \mathrm{nmol} / \mathrm{g}$; vehicle group, $982.80 \pm 79.07 \mathrm{nmol} / \mathrm{g} ; \quad$ carbenoxolone group, $1195.60 \pm$ $37.57 \mathrm{nmol} / \mathrm{g} ;$ C. cajucara group, $1286.51 \pm 93.15 \mathrm{nmol} / \mathrm{g}$. GSH, glutathione. 
Table 2. Effect of $C$. CajuCara Essential Oil (100 Mg/Kg) on Ethanol-Induced Gastric Ulcer Area (mm2) in Rats $(N=7)$ Pretreated with N-Ethylmaleimide (10 MG/KG) or N-Nitro-L-Arginine Methyl Ester (70 Mg/Kg)

\begin{tabular}{llll}
\hline Pretreatment $($ i.p $)$ & \multicolumn{1}{c}{ Saline } & \multicolumn{1}{c}{ NEM } & L-NAME \\
\hline Treatment $($ oral $)$ & Vehicle & Vehicle & Vehicle \\
Ulcer area $\left(\mathrm{mm}^{2}\right)$ & $139.05 \pm 19.21$ & $1229.70 \pm 141.25^{b}$ & $511.94 \pm 80.96^{b}$ \\
Treatment $($ oral $)$ & Croton cajucara & Croton cajucara & Croton cajucara $^{\text {a }}$ \\
Ulcer area $\left(\mathrm{mm}^{2}\right)$ & $0.55 \pm 0.30^{\mathrm{a}}$ & $356.63 \pm 53.69^{\mathrm{a}, \mathrm{c}}$ & $40.08 \pm 18.23^{\mathrm{a}}$ \\
Gastroprotection $(\%)$ & 99.6 & 71.0 & 92.2 \\
\hline
\end{tabular}

Values are expressed as the mean \pm standard error. Unpaired $t$-test.

${ }^{\mathrm{a}} P<.01$ in the column (same pretreatment).

${ }^{\mathrm{b}} P<.01$ in the same row (same oral treatment-vehicle).

${ }^{\mathrm{c}} P<.01$ in the same row (same oral treatment-Croton cajucara).

IP, intraperitoneally treated; L-NAME, N-nitro-L-arginine methyl ester; NEM, N-ethylmaleimide.

tion causes gastric damage by a variety of pathways, such as decreasing reduced glutathione levels, reducing protective factors of the gastric mucosa,${ }^{24}$ depleting mucus in the gastric surface, ${ }^{25}$ and inhibiting prostaglandin synthesis. ${ }^{26}$ Gastrointestinal diseases related to alcohol consumption play an important role in clinical gastroenterology. ${ }^{27}$ In the present study, we examined the protective mechanism of $C$. cajucara against gastric mucosa damage produced by absolute ethanol. When rats were pretreated with $C$. cajucara before ethanol administration, gastric ulcer formation was completely suppressed. This finding suggests that $C$. cajucara acts as a direct cytoprotective agent.

The results of histologic analysis confirmed that ethanol administration caused gastric mucosal injuries characterized by mucosal hemorrhage, glandular damage, epithelial desquamation, and eosinophilic infiltration, as described by Jahovic et al. ${ }^{19}$ The group treated with vehicle clearly produced the expected characteristics of necrotizing mucosal lesions. However, the pretreatment with C. cajucara inhibited such alterations, including complete inhibition of hemorrhage and eosinophilic infiltration. These data revealed a correlation with the absence of gastric ulcers, confirming the effectiveness of the treatment and indicating a significant protective effect from $C$. cajucara against absolute ethanol.

Ulcerogenic substances cause dissipation of the mucous gel and phospholipid layer, leading to acid back-diffusion and mucosal injury. ${ }^{28}$ According to the periodic acid-Schiff staining, the increase in the mucus secretion is part of the $C$. cajucara gastroprotective mechanism.

Recently, the importance of gastroprotective effects of molecular chaperones, mainly HSP-70 families, was reported in several experimental models. ${ }^{29}$ HSP-70 is a protein produced from different forms of stress that protects cellular homeostatic processes from injuries through the preservation of normal protein structure and reparation or removal of damaged proteins, thereby offering protection from gastric ulcer formation. ${ }^{30}$ HSP-70 expression is associated with adaptive cellular protection against ethanol ingestion. ${ }^{31}$ Immunomarked area for HSP-70-positive cells in the $C$. cajucara and carbenoxolone groups and its expression concentrated in microscopically injured areas indicated that the treatments stimulate adaptive cytoprotection through HSP-70 expression.

VIP equilibrates beneficial and harmful effects of histamine, which is an important mediator for tissue repair and healing, in addition to presenting antioxidant and antiinflammatory activities. ${ }^{32}$ However, the gastroprotective effect of C. cajucara is not involved with histamine level control by VIP activity.

Another aggressive mechanism by which ethanol attacks gastric mucosa is the impairment of glutathione levels. Glutathione is an important antioxidant found in most mammalian cells. ${ }^{33}$ It is essential for maintaining gastric mucosa integrity, preventing injuries caused by noxious agents, and protecting the cell from free-radical-induced damage. ${ }^{34}$ However, our results showed that the gastroprotective effect of $C$. cajucara does not act through this antioxidant pathway.

The mucous synthesis that strengthens the mucosa barrier against harmful agents also has an important role in gastric protection. Accordingly, the literature reports that endogenous non protein-sulfhydryl (NP-SH) compounds are the key agents in mucosal protection against ethanol-induced gastric injury. ${ }^{35} \mathrm{NP}-\mathrm{SH}$ compounds bind the free radicals formed from the ethanol action and are also involved in controlling the production and nature of mucus and in recycling antioxidants. ${ }^{36}$ Our findings agree with earlier reports showing depletion of NP-SH compounds in ethanolinduced gastric lesions. ${ }^{37}$ The decrease in gastric ulcer area observed after pretreatment with NEM in animals treated with $C$. cajucara indicated a significant improvement in the depleted level of NP-SH concentration, thus indicating a strong participation of the endogenous NP-SH in the gastroprotective effect of $C$. cajucara.

Previous studies focused on nitric oxide as a gastroprotective factor that is released in large qualities and contributes to decreasing the lesions, ${ }^{38}$ given that nitric oxide is important in the regulation of acid and alkaline secretion, mucous secretion, and gastric mucosal blood flow. ${ }^{39}$ However, our results did not show an increase in the gastric ulcer area after blocking of nitric oxide production with LNAME, suggesting that the gastroprotective effect of $C$. cajucara is not mediated by the nitric oxide pathway. 
Since the 1982 discovery by Marshall and Warren (2005 Nobel Laureates for Medicine) that the bacterium H. pylori is an etiologic agent of gastric ulcers, the pathogen has been shown to be a causative agent of disease states of varying degrees of severity, including chronic gastritis, peptic ulcer disease, gastric adenocarcinoma, and gastric mucosa-associated lymphoid tissue lymphoma. ${ }^{40}$ Reports in literature have shown that an MIC of $250 \mu \mathrm{g} / \mathrm{mL}$ or less is an interesting result for natural products. ${ }^{41,42}$ Thus, C. cajucara presented satisfactory activity against other important factor in gastric ulcers development. It is possible that $C$. cajucara could be administered as a supplement to enhance the efficacy of the actual antibacterial therapies.

In conclusion, $C$. cajucara essential oil presented gastroprotective activity in ethanol-induced gastric ulcer. It completely prevented the formation of gastric ulcers, reduced epithelial desquamation and glandular damage, and avoided mucosal hemorrhage and eosinophilic infiltration in the gastric mucosa. This effect was not due to the maintenance of glutathione levels, was not modulated by nitric oxide release, and did not activated VIP expression. It was due to HSP-70 expression, mucous secretion, and increase in the bioavailability of gastric sulfhydryl groups, which led to a reduction in the gastric oxidative injury induced by ethanol. These data confirm knowledge from the northern region of Brazil that indicates this plant as an option for gastric ulcer treatment.

\section{ACKNOWLEDGMENT}

This work was supported by Fundação de Amparo a Pesquisa do Estado de São Paulo (07/531283 and 06/ 55542-9).

\section{AUTHOR DISCLOSURE STATEMENT}

No competing financial interests exist.

\section{REFERENCES}

1. Silva MI, Moura BA, de Aquino Neto MR, et al.: Gastroprotective activity of isopulegol on experimentally induced gastric lesions in mice: investigation of possible mechanisms of action. Naunyn Schmiedebergs Arch Pharmacol 2009;380:233245.

2. Amaral JF, Silva MI, Neto MR, et al.: Antinociceptive effect of the monoterpene R-(+)-limonene in mice. Biol Pharm Bull 2007;30:1217-1220.

3. De Sousa DP, Gonçalves JCR, Quintans-Júnior L, et al.: Study of anticonvulsant effect of citronellol, a monoterpene alcohol, in rodents. Neurosci Lett 2006;401:231-235.

4. Hiruma-Lima CA, Gracioso JS, Bighetti EJ, et al.: Effect of essential oil obtained from Croton cajucara Benth. on gastric ulcer healing and protective factors of the gastric mucosa. Phytomedicine 2002;9:523-529.

5. Whelan AM, Jurgens TM, Lord L: Evaluating the quality of randomized controlled trials that examine the efficacy of natural health products: a systematic review of critical appraisal instruments. Evid Based Complement Alternat Med 2009;6:441-448.
6. Vonkeman HE, Klok RM, Postma MJ, Brouwers JR, Van de Laar MA: Direct medical costs of serious gastrointestinal ulcers among users of NSAIDs. Drugs Aging 2007;24:681-690.

7. Laine L, Takeuchi K, Tarnawski A: Gastric mucosal defense and cytoprotection: bench to bedside. Gastroenterology 2008;135: 41-60.

8. Chan FL, Leung WK: Peptic ulcer disease. Lancet. 2002;360: 933-941.

9. Lorenzi H, Abreu Matos FJ: Plantas Medicinais no Brasil. Instituto Plantarum, Nova Odessa, 2002, p. 206.

10. Carvalho JC, Silva MF, Maciel MA, et al.: Investigation of anti-inflammatory and antinociceptive activities of transdehydrocrotonin, a 19-nor-clerodane diterpene from Croton cajucara. Planta Med 1996;62:402-404.

11. Di Stasi LC, Hiruma CA, Guimarães EM, Santos CM: Medicinal plants popularly used in Brazilian Amazon. Fitoterapia 1994;65:529-540.

12. Souza Brito ARM, Nunes DS: Ethnopharmacology and sustainable development of new plant-derived drugs. Ciên Cult 1997; 49:402-408.

13. Maciel MAM, Pinto AC, Veiga Jr VF: Plantas medicinais: a necessidade de estudos multidisciplinares. Quím Nova 2002;25: 429-438.

14. Hiruma-Lima CA, Gracioso JS, Nunes DS, Souza Brito ARM: Effects of an essential oil from the bark of Croton cajucara Benth. on experimental gastric ulcer models in rats and mice. $\underline{J}$ Pharm Pharmacol 1999;51:341-346.

15. Itokawa $\mathrm{H}$, Ichihara $\mathrm{Y}$, Kojima $\mathrm{H}$, Watanabe $\mathrm{K}$, Takeya K: NorClerodane diterpenes from Croton cajucara. Phytochemistry 1989;28:1667-1669.

16. San Gil RAS, Albuquerque MG, Bicca de Alencastro R, et al.: Solid-state ${ }^{13} \mathrm{C}$ NMR and molecular modeling studies of acetyl aleuritolic acid obtained from Croton cajucara Benth. $\mathrm{J} \mathrm{Mol}$ Struct 2008;885:82-88.

17. De Paula ACB, Gracioso JS, Toma W, et al:: The antiulcer effect of Croton cajucara Benth in normoproteic and malnourished rats. Phytomedicine 2008;15:815-825.

18. Morimoto Y, Shimohara K, Oshima S, Sukamoto T: Effects of the new anti-ulcer agent KB-5492 on experimental gastric mucosal lesions and gastric mucosal defensive factors, as compared to those of teprenone and cimetidine. Jpn J Pharmacol 1991;57: 495-505.

19. Jahovic N, Erkanli G, Isseri S, Arbak S, Alican I: Gastric protection by alpha-melanocyte-stimulating hormone against ethanol in rats: involvement of somatostatin. Life Sci 2007;80: 1040-1045.

20. Anderson ME: Determination of glutathione and glutathione disulfide in biological samples. Methods Enzymol 1985;113:548555.

21. Matsuda H, Li Y, Yoshikawa M: Roles of capsaicin-sensitive sensory nerves, endogenous nitric oxide, sulphydryls, and prostaglandins in gastroprotection by mormodin Ic, an oleanolic acid oligoglycoside, on ethanol-induced gastric mucosal lesion in rats. Life Sci 1999;65:27-32.

22. Park BS, Lee HK, Lee SE, et al.: Antibacterial activity of Tabebuia impetiginosa Martius ex DC (Taheebo) against Helicobacter pylori. J Ethnopharmacol 2006;105:255-262.

23. Clinical and Laboratory Standards Institute: Methods for antimicrobial dilution and disk susceptibility testing of infrequently isolated or fastidious bacteria. Tentative standards M45-A and 
M02-A9. National Committee for Clinical Laboratory Standards, 2008.

24. Bafna PA, Balaraman R: Anti-ulcer and antioxidant activity of DHC-1, a herbal formulation. J Ethnopharmacol 2004;90:123127.

25. Al-Howiriny T, Al-Sohaibani M, El-Tahir K, Rafatullah S: Prevention of experimentally-induced gastric ulcers in rats by an ethanolic extract of "Parsley" Petroselinum crispum. Am J Chin Med 2003;31:699-711.

26. Abdel-Salam OM, Czimmer J, Debreceni A, Szolcsányi J, Mózsik G: Gastric mucosal integrity: gastric mucosal blood flow and microcirculation. an overview. J Physiol Paris 2001;95:105127.

27. Siegmund S, Haas S, Schneider A, Singer MV: Animal models in gastrointestinal alcohol research-a short appraisal of the different models and their results. Best Pract Res Clin Gastroenterol 2003; 17:519-542.

28. Darling RL, Romero JJ, Dial EJ, et al.: The effects of aspirin on gastric mucosal integrity, surface hydrophobicity, and prostaglandin metabolism in cyclooxygenase knockout mice. Gastroenterology 2004;127:94-104.

29. Matsuhashi T, Otaka M, Odashima M, et al.: Protective effect of a novel rice extract against ethanol-induced gastric mucosal injury in rat. Dig Dis Sci 2007;52:434-441.

30. Tytell M, Hooper PL: Heat shock proteins: new keys to the development of cytoprotective therapies. Expert Opin Ther Targets 2001;5:267-287.

31. Yeo M, Kim DK, Cho SW, Hong HD: Ginseng, the root of Panax ginseng C.A. Meyer, protects ethanol-induced gastric damages in rat through the induction of cytoprotective heat-shock protein 27. Dig Dis Sci 2008;53:606-613.

32. Tunçel N, Tunçel M, Aboul-Enein HY: Effects of the vasoactive intestinal peptide on stress-induced mucosal ulcers and modulation of methylation of histamine in gastric tissue of the rats. $I l$ Fármaco 2003;58:449-454.
33. Devi RS, Narayan S, Vani G, Shyamala Devi CS: Gastroprotective effect of Terminalia arjuna bark on diclofenac sodium induced gastric ulcer. Chem Biol Interact 2007;167:71-83.

34. Ozbakis Dengiz G, Odabasoglu F, Halici Z, Cadirci E, Suleyman $\mathrm{H}$ : Gastroprotective and antioxidant effects of montelukast on indomethacin-induced gastric ulcer in rats. J Pharm Sci 2007; 105:94-102.

35. Szabo S, Vattay P: Experimental gastric and duodenal ulcers. Advances in pathogenesis. Gastroenterol Clin North Am 1990; 19:67-85.

36. Banerjee D, Maity B, Nag SK, Bandyopadhyay SK, Chattopadhyay S: Healing potential of Picrorhiza kurroa (Scrofulariaceae) rhizomes against indomethacin-induced gastric ulceration: a mechanistic exploration. BMC Complement Altern Med 2008; 8:3-16.

37. Alqasoumi S, Al-Sohaibani M, Al-Howiriny T, Al-Yahya M, Rafatullah S: Rocket Eruca sativa: a salad herb with potential gastric anti-ulcer activity. World J Gastroenterol 2009;15:19581965.

38. Kwiecieñ S, Pawlik MW, Brzozowski T, et al.: Nitric oxide (no)releasing aspirin and (no) donors in protection of gastric mucosa against stress. J Physiol Pharmacol 2008;59:103-115.

39. Chandranath SI, Bastaki SM, Singh J: A comparative study on the activity of lansoprazole, omeprazole and PD-136450 on acidified ethanol and indomethacin-induced gastric lesions in the rat. Clin Exp Pharmacol Physiol 2002;29:173-180.

40. Peek RM Jr, Crabtree JE: Helicobacter infection and gastric neoplasia. J Pathol 2006;208:233-248.

41. Lima ZP, Dos Santos RD, Torres TU, et al.: Byrsonima fagifolia: an integrative study to validate the gastroprotective, healing, antidiarrheal, antimicrobial and mutagenic action. $\underline{J \text { Ethno- }}$ pharmacol 2008;120:149-160.

42. Moraes TM, Rodrigues CM, Kushima H, et al:: Hancornia speciosa: indications of gastroprotective, healing and anti-Helicobacter pylori actions. J Ethnopharmacol 2008;120:161-168. 
This article has been cited by:

1. Ariane Leite Rozza, Cláudia Helena Pellizzon. 2013. Essential oils from medicinal and aromatic plants: a review of the gastroprotective and ulcer-healing activities. Fundamental \& Clinical Pharmacology 27:1, 51-63. [CrossRef] 